\title{
DINAMIKA PEMILIHAN KEPALA DAERAH LANGSUNG DI PROVINSI SULAWESI TENGGARA
}

\author{
Teguh Setyabudi ${ }^{1}$, Sampara Lukman $^{2}$, Aries Djaenuri $^{3}$, Khasan Effendy ${ }^{4}$ \\ 1,2,3,4 Institut Pemerintahan Dalam Negeri (IPDN) \\ Email: teguh.setyabudi@gmail.com
}

\begin{abstract}
Abstrak
Penelitian ini membahas tentang dinamika pemilihan kepala daerah langsung di tingkat provinsi dengan studi kasus pemilihan Gubernur dan Wakil Gubernur Provinsi Sulawesi Tenggara tahun 2018. kajian ini tidak serta merta dimaknai sebagai perubahan pilkada langsung menjadi tidak langsung, melainkan sebagai jalan tengah dalam membuat kebijakan di masa yang akan datang. Kajian ini diawali dengan melakukan telaah ulang terhadap berbagai kendala pilkada langsung sebagai bentuk evaluasi. Dengan demikian, pelaksanaan pilkada langsung dapat meningkatkan kualitas demokrasi di tingkat lokal dan nasional. Penelitian lanjutan sangat dianjurkan setelah penelitian ini.
\end{abstract}

Kata Kunci: Demokrasi, Pilkada, Dinamika.

\begin{abstract}
This study discusses the dynamics of direct regional head elections at the provincial level with a case study of the election of the Governor and Deputy Governor of Southeast Sulawesi Province in 2018. This study is not necessarily interpreted as a change in direct local elections to be indirect, but rather as a middle way in making policies in the future. will come. This study begins with a review of various direct election problems as a form of evaluation. Thus, the implementation of direct elections can improve the quality of democracy at the local and national levels. Further research is highly recommended after this study.
\end{abstract}

Keywords: Democracy, Local Election, Dynamics.

\section{A. PENDAHULUAN}

Pelaksanaan pilkada langsung merupakan aktivitas penting bagi bekerjanya demokrasi di tingkat lokal. Pilkada langsung memberikan ruang yang lebih besar kepada masyarakat untuk terlibat dalam pembuatan kebijakan di daerah sebagai bentuk pendalaman demokrasi guna mewujudkan tata kelola pemerintahan yang baik dan efektif. Jika dilihat dari sudut pandang demokrasi Schumpeterian (1972), pilkada langsung menjadi arena bagi terjadinya proses rotasi kepemimpinan lokal secara reguler sekaligus sebagai tradisi baru karena terjadi perubahan metode, dari pemilihan melalui Dewan Perwakilan Rakyat Daerah (DPRD) menjadi pemilihan langsung oleh rakyat Lay (2007). Para ilmuwan politik menyebutkan bahwa pilkada langsung adalah investasi penting sebagai pendalaman 
demokrasi di tingkat lokal karena menyangkut pendidikan politik masyarakat Diamond (1996).

Lebih dari itu, Lay (2007) juga mengatakan perubahan pilkada secara tidak langsung melalui DPRD menjadi pemilihan langsung oleh rakyat menjadi dasar terjadinya pertukaran elit secara reguler sekaligus menjadi pendidikan politik secara lebih luas terutama dalam kenormalan kalah dan menang dalam kontestasi yang jujur dan adil. Sementara Diamon (1996) mengatakan bahwa pilkada langsung adalah instrumen yang tepat untuk proses pendalaman demokrasi (deepening democracy) dan upaya mewujudkan tata kelola pemerintahan yang baik dan efektif Hanafi (2014). Fung dan Olin-Wright (2003) juga mengatakan pendalaman demokrasi diperlukan untuk memenuhi gagasan sentral mengenai demokrasi politik. Dengan demikian, pilkada langsung memberikan ruang bagi banyak orang untuk terlibat dalam proses kebijakan di pemerintah lokal maupun keterlibatan aktif warga secara lebih luas Stewart (1996).

Secara praktis, penelitian ini menarik karena hingga saat ini Indonesia masih mencari praktik berdemokrasi terutama di tingkat lokal yang sesuai dengan jatidiri bangsa. Pada masa orde lama (1945-1965), Indonesia pernah menerapkan mekanisme demokrasi secara tidak langsung ketika Presiden dan kepala daerah dipilih oleh lembaga legislatif. Kondisi yang hampir sama juga terjadi di era orde baru tahun 1966-1998. Sekalipun sistem politik kala itu bersifat otoritarianisme, namun mekanisme dalam seleksi kepemimpinan politik di semua tingkatan tidak banyak mengalami perubahan. Eksekutif (presiden dan kepala daerah) masih dipilih melalui representasi masyarakat yang sebelumnya sudah dipilih dan duduk sebagai perwakilan rakyat di wilayah tertentu, baik di Majelis Permusyawaratan Rakyat (MPR), Dewan Perwakilan Rakyat (DPR), maupun Dewan Perwakilan Rakyat Daerah (DPRD).

Perubahan secara signifikan baru terjadi pasca orde baru runtuh tahun 1998, saat mana rakyat dapat secara langsung memilih presiden dan kepala daerah. Mengacu pada regulasi yang berlaku (UU No 32 Tahun 2014), pilkada langsung baru mulai diterapkan pada tahun 2005 karena sejumlah alasan yang berkembang pada saat itu. Dalam perjalanan waktu, salah satu putusan Mahkamah Konstitusi (MK) menyatakan bahwa pengaturan pilkada adalah bagian dari rezim pemilu, bukan rezim pemerintahan daerah. Oleh karena itu, pilkada didorong seirama dengan pemilihan presiden/wakil presiden yang sudah terlebih dahulu dilakukan secara langsung oleh rakyat. Putusan tersebut secara langsung juga berimbas pada upaya revisi Undang-Undang Nomor 32 Tahun 2004 tentang Pemerintahan Daerah dan juga perubahan substansial undang-undang pilkada dan pilkades. 
Penelitian ini hadir untuk melihat secara lebih serius tentang rekonstruksi pilkada langsung dengan mengambil studi kasus Pilkada Provinsi Sulawesi Tenggara tahun 2018. Caranya dengan melihat dinamika politik yang meliputi sejumlah aspek penting dan berdampak luas terutama dalam upaya mengkonsolidasikan demokrasi melalui mekanisme yang lebih sederhana guna menciptakan kesejahteraan sebagai tujuan berdemokrasi. Hal tersebut tidak terlepas dari posisi gubernur yang memiliki fungsi ganda: sebagai kepala daerah otonom dan perpanjangan tangan pemerintah pusat di daerah. Provinsi berdasarkan Undang-Undang nomor 23 tahun 2014 tentang Pemerintahan Daerah kini memiliki kewenangan sampai dengan level teknis atau bersentuhan dengan masyarakat dalam beberapa urusan. Beberapa kewenangan pemerintah kabupaten/kota bahkan beralih menjadi kewenangan provinsi, misalnya tentang pengelolaan pendidikan menengah atas, pertambangan, kehutanan, dan juga kelautan.

Pemilihan Gubernur dan Wakil Gubernur secara langsung di Provinsi Sulawesi Tenggara dilaksanakan pada tanggal 27 Juni 2018. Seperti halnya pemilihan gubernur dan wakil gubernur sebelumnya, pilkada langsung tahun 2018 juga diikuti oleh tiga pasangan calon. Ketiga pasangan calon tersebut semuanya diusung oleh partai politik dan ketiganya juga merupakan pemain lama di panggung perpolitikan di Sulawesi Tenggara. Ketiga pasangan calon tersebut merupakan para mantan kepala daerah bupati/wali kota di wilayah Sulawesi Tenggara. Oleh karena itu, ketiganya dinilai sudah mempunyai pengalaman di pemerintahan yang cukup banyak dan elektabilitasnya pun semuanya tinggi dengan basis massa masing-masing.

Sama halnya dengan pemilihan gubernur sebelum-sebelumnya, ketiga pasang calon tersebut masing-masing merupakan kombinasi antara wilayah daratan dan kepulauan. Di satu sisi, poin ini menjelaskan kuatnya ikatan primordial masyarakat Sulawesi Tenggara dalam memilih pemimpin. Keterwakilan etnis atau kelompok sangat penting untuk memperkuat legitimasi di masyarakat. Di sisi lain, kuatnya ikatan primordial jika tidak mampu dikelola dengan baik, maka bisa memunculkan konflik baru, terutama tentang SARA.

Berikut ketiga pasang calon Gubernur dan Wakil Gubernur Provinsi Sulawesi Tenggara pada pilkada 2018 sesuai hasil pleno penetapan pasangan calon oleh KPU Nomor 14/PL.03.3-Kpt/74/Prov/II/2018 tanggal 12 Februari 2018. 
Tabel 1 Pasangan Calon Pemilihan Gubernur-Wakil Gubernur Provinsi Sulawesi Tenggara Tahun 2018

\begin{tabular}{|c|l|c|c|}
\hline No & \multicolumn{1}{|c|}{ Pasangan Calon } & Partai Pendukung & Jumlah \\
\hline 1 & $\begin{array}{l}\text { H. Ali Mazi, SH. Dan Dr. H. } \\
\text { Lukman Abunawas }\end{array}$ & Golkar (7 kursi); NasDem (3 kursi) & 10 Kursi \\
\hline 2 & $\begin{array}{l}\text { Dr. Ir. H. Asrun, M.Sc., } \\
\text { Eng.dan Ir. Hugua }\end{array}$ & $\begin{array}{l}\text { PAN (9 kursi); PDIP (5 kursi); PKS } \\
\text { (5 kursi); Gerindra (4 kursi); } \\
\text { Hanura (3 kursi) }\end{array}$ & 26 Kursi \\
\hline 3 & $\begin{array}{l}\text { Rusda Mahmud dan Ir. H. La } \\
\text { Ode M. Sjafei Kahar }\end{array}$ & $\begin{array}{c}\text { Demokrat (6 kursi); PPP (2 kusi); } \\
\text { \& PKB (1 kursi) }\end{array}$ & 9 Kursi \\
\hline
\end{tabular}

Sumber: KPU Provinsi Sulawesi Tenggara, 2018

Tingkat partisipasi memilih masyarakat Sulawesi Tenggara dalam setiap pemilu semakin meningkat. Pada pemilihan gubernur tahun 2012, tingkat partisipasi masyarakat hanya mencapai $64,1 \%$. Sementara pada tahun 2018, tingkat partisipasinya meningkat $4 \%$ menjadi $69,51 \%$ atau 1.157 .391 dari 1.664 .957 total pemilih di Sulawesi Tenggara. Jika dilihat secara lebih rinci, partisipasi perempuan lebih tinggi dibandingkan dengan pemilih laki-laki dengan selisih 4,49\%. Sedangkan tingkat partisipasi difabel mencapai $71,24 \%$ atau 2.732 dari total 3.782 pemilih. Dari total suara di atas, KPU Provinsi Sulawesi Tenggara sesuai keputusan KPU Provinsi Sulawesi Tenggara nomor 63/PL.03.7-Kpt/74/Prov/VIII/2018 tentang Penetapan Pasangan Calon Gubernur dan Wakil Gubernur Terpilih dalam Pemilihan Gubernur dan Wakil Gubernur Sulawesi Tenggara Tahun 2018, menetapkan pasangan H. Ali Mazi, S.H dan Dr. H. Lukman Abunawas pasangan yang hanya didukung Golkar dan Nasdem tersebut menang dengan perolehan suara 495.880 atau 43,68\% dari total suara sah. Kemudian disusul pasangan Rusda-Syafei yang didukung Demokrat, PPP, dan PKB dengan perolehan 358.537 suara atau 31,58\%. Sementara pasangan Asrun-Hugua yang didukung lebih dari setengah kursi parlemen justru hanya mendapatkan 280.762 suara atau $24,73 \%$ dari total suara sah. Asrun yang sebelumnya sudah digadang-gadang menjadi calon terkuat harus mengakui kekalahannya atas Ali-Lukman. Kondisi ini menjadi contoh praktis, bahwa dukungan partai politik di parlemen lokal tidak menjadi jaminan dalam meraih kemenangan.

Tabel 2 Perolehan Suara Pemilihan Gubernur dan Wakil Gubernur Provinsi Sulawesi Tenggara 2018

\begin{tabular}{|c|l|c|c|}
\hline No & \multicolumn{1}{|c|}{ Pasangan Calon } & Perolehan Suara & Persentase \\
\hline 1 & H. Ali Mazi, SH. - Dr. H. Lukman Abunawas & 495.880 & $43,68 \%$ \\
\hline 2 & Dr. Ir. H. Asrun, M.Sc., Eng. - Ir. Hugua & 280.762 & $24,73 \%$ \\
\hline 3 & $\begin{array}{l}\text { Rusda Mahmud - Ir. H. La Ode M. Sjafei } \\
\text { Kahar }\end{array}$ & 358.537 & $31,58 \%$ \\
\hline \multicolumn{2}{|c|}{ Total } & $\mathbf{1 . 1 3 5 . 1 7 9}$ & $\mathbf{1 0 0 \%}$ \\
\hline
\end{tabular}

Sumber: KPU Provinsi Sulawesi Tenggara, 2018 
Kemenangan Ali-Lukman menjadi bukti baru bahwa solidaritas primordial masih sangat kuat. Hal tersebut bisa terlihat dari prosentase kemenangan di setiap kabupaten dengan rata-rata di atas 50\% dari suara sah. Ali Mazi yang merupakan pria kelahiran Buton mampu membangun komunikasi bahwa dia adalah representasi yang tepat bagi orang di wilayah kepulauan. Sementara Lukman representasi dari masyarakat daratan. Kemenangan Ali Mazi dalam pemilu 2018 juga menambah catatan semakin banyaknya orang kepulauan yang duduk menjadi Gubernur Sulawesi Tenggara.

Ali Mazi sendiri tercatat pernah menjadi Gubernur Sulawesi Tenggara periode 20032008. Namun pada tahun 2006 sempat diberhentikan sementara karena kasus hukum. Kemudian pada tahun 2007, Ali Mazi kembali menjabat sebagai gubernur setelah kasus hukumnya selesai. Ali Mazi juga pernah tercatat mencalonkan diri untuk periode keduanya pada pilkada 2008, namun kalah dengan pasangan Nur Alam-Saleh Lasata. Jiwa kepemimpinan yang tidak pantang menyerah dia ekspresikan dengan kembali kembali mencoba mencalonkan diri pada pilkada gubernur tahun 2012, namun gagal mendapatkan tiket dari partai politik. Akhirnya, pada pilkada 2018, Ali Mazi kembali maju dengan dukungan Golkar dan Nasdem dan menjadi pemenang dengan perolehan suara sah sebanyak 43,68\%. Bersama Lukman Abunawas, dia meletakkan dasar pembangunan Sulawesi Tenggara melalui program Sultra Emas dengan lima program utama: Sultra Cerdas, Sultra Sehat, Sultra Beriman dan Berbudaya, Sultra Produktif, dan Sultra Peduli.

\section{B. METODE}

Sejalan dengan tujuan penelitian yang berusaha untuk menjelaskan, mengkaji, menganalisis dan mengeksplorasi proses pemilihan kepala daerah langsung di Provinsi Sulawesi Tenggara tahun 2018, maka desain penelitian menggunakan metode kualitatif. Proses penelitian kualitatif oleh peneliti dilakukan dengan cara mengajukan berbagai pertanyaan yang relevan dengan topik (Data Primer) penelitian sebagai upaya menggali pandangan, gagasan, ide dan fakta-fakta dari informan tentang topik penelitian untuk kemudian data dan informasi tersebut dikelompokkan, diberi kode, ditriangulasi kebenarannya serta dilakukan analisis secara induktif sepanjang proses penelitian berlangsung. Data Sekunder di perlukan sebagai tambahan untuk lebih mempertajam penalitian melalui penelusuran literature-literatur yang terkait dengan penelitian. 


\section{HASIL DAN PEMBAHASAN}

Pelaksanaan pemilihan gubernur dan wakil gubernur Sulawesi Tenggara tahun 2018 tidak terlepas dari berbagai dinamika sosial politik. Pada masa pra-tahapan pilkada, perbincangan di warung kopi sampai pertemuan-pertemuan formal sudah mulai memanas. Beberapa isu yang sering muncul misalnya tentang lobi-lobi politik, kasak-kusuk soal harga „sewa perahu“e, biaya politik untuk merebut kemenangan, pembentukan tim sukses, hingga survei-survei elektabilitas yang terus dilakukan oleh tim sukses masing-masing. Masyarakat juga sudah mulai disuguhkan iklan-iklan politik berupa poster, baliho, atau umbul-umbul sebagai pemantik sebelum pilkada berlangsung. Isu-isu tersebut semakin memanas ketika beberapa nama yang muncul di permukaan justru orang-orang yang pernah memiliki masalah dengan lembaga rasuah.

Sementara itu, tahapan pilkada dinamika politik lebih banyak yang berkaitan dengan urusan administratif dan persiapan-persiapan teknis. Misalnya, Bawaslu Provinsi Sulawesi Tenggara (2018) mencatat ditemukannya beberapa data pemilih yang bermasalah seperti Nomor Induk Kependudukan (NIK) ganda, NIK dan nama ganda, NIK invalid, NIK indikasi invalid, NIK dan tanggal, bulan, tahun tidak sesuai, NIK dan jenis kelamin tidak sesuai, belum berumur 17 tahun dan belum menikah, NKK dan NIK tidak ada, berumur 0 (nol) dan di beberapa wilayah juga muncul masalah hilangnya nama pemilih yang sudah pernah dicatat dalam DPT tanpa alasan yang jelas.Catatan KPU Provinsi Sulawesi Tenggara (2018), dari total daftar pemilih sementara (DPS) yang mencapai 1.666 .546 pemilih, karena berbagai permasalahan di atas berubah menjadi 1.628 .320 pemilih sesuai dengan daftar pemilih tetap (DPT) yang disahkan pada 21 April 2018. Rinciannya, 812.996 pemilih laki-laki dan 815.324 pemilih perempuan.

Dinamika politik semakin memanas ketika masuk pada tahap pendaftaran pasangan calon. Pada tahap ini, masalah muncul dari konflik internal partai politik pendukung, yaitu lahirnya kepengurusan ganda dan perbedaan persepsi serta kepentingan antara Dewan Pengurus Pusat (DPP) dan Dewan Pengurus Daerah (DPD) dalam menentukan siapa yang akan diusung. Jika kondisi tersebut tidak dimanajemen dengan baik, maka pasangan calon akan sulit mendapatkan keabsahan tanda tangan dari pengurus partai politik. Selain itu, kondisi tersebut juga berpotensi pecahnya dukungan massa yang dikarenakan perbedaan persepsi antara DPP dengan DPD. Dampak paling parah adalah munculnya konflik antar pendukung atau kader partai. 
Masuk dalam tahapan teknis pengadaan dan pendistribusian perlengkapan pemungutan dan penghitungan suara, terdapat beberapa masalah. Pertama, jumlah dan bentuk logistik tidak sesuai dengan spesifikasi yang telah ditetapkan dalam peraturan KPU Nomor 9 Tahun 2017 tentang norma, standar, prosedur, kebutuhan pengadaan dan pendistribusian perlengkapan penyelenggaraan pemilihan Gubernur dan Wakil Gubernur, Bupati dan Wakil Bupati dan/atau Wali Kota dan Wakil Wali Kota Tahun 2018. Selain itu, produksi dan pencetakan logistik juga tidak sesuai dengan program, jadwal, dan tahapan dalam pemilihan Gubernur dan Wakil Gubernur Provinsi Sulawesi Tenggara Tahun 2018. Hasil pencetakan bahan kampanye pun dianggap bermasalah karena perbedaan kualitas pada gambar masing-masing pasangan calon. Pasangan calon nomor 1 terlihat sangat terang dan jelas, sedangkan calon pasangan lain gambarnya gelap dan tidak jelas. Kedua, perusahan pengadaan tidak tepat waktu dalam pengadaan dan distribusi logistik. Kenyataan tersebut masih diperparah dengan kondisi geografis yang sulit untuk dijangkau melalui transportasi darat. Akibatnya, di beberapa wilayah distribusi mengalami keterlambatan yang cukup lama. Dan yang berbahaya adalah ditemukannya surat suara yang rusak hampir di seluruh kabupaten/kota di Sulawesi Tenggara. Pada tahapan inti pemungutan suara ditemukan beberapa kejanggalan dan permasalahan yang cukup serius. Baik yang bersifat administratif maupun bersifat politis.

Selain berbagai permasalahan di atas, pelaksanaan pesta rakyat pemilihan Gubernur dan Wakil Gubernur Sulawesi Tenggara juga dihadapkan pada dinamika politik praktis seperti tingginya biaya politik dan maraknya politik uang, maraknya pemungutan suara ulang, serta politisasi birokrasi. Secara lebih rinci, berikut beberapa dinamika politik yang terjadi pada saat pemilihan Gubernur dan Wakil Gubernur Sulawesi Tenggara tahun 2018.

\section{Maraknya Pemungutan Suara Ulang pada Pilkada Provinsi Sulawesi Tenggara tahun 2018}

Pemilihan Gubernur dan Wakil Gubernur Provinsi Sulawesi Tenggara tahun 2018 tidak terlepas dari berbagai pelanggaran administratif maupun hukum yang terjadi di tempat pemungutan suara (TPS). Akibatnya, beberapa TPS harus melakukan pemungutan suara ulang (PSU) agar hasilnya bisa sah secara hukum. Mengutip data Bawaslu Provinsi Sulawesi Tenggara (2018), Provinsi Sulawesi Tenggara harus melaksanakan PSU di 41 TPS yang tersebar di 9 kabupaten/kota. Jumlah ini membawa Sulawesi Tenggara sebagai daerah yang paling banyak melaksanakan PSU. Pelaksanaan PSU sendiri tidak terlepas dari rekomendasi 
panitia pengawas pemilu (Panwaslu) yang menemukan berbagai pelanggaran usai pencoblosan. Seperti pembukaan kotak suara yang tidak prosedural atau pemilih yang tidak terdaftar dalam daftar pemilih.

Penyebab berbagai pelanggaran cukup banyak, antara lain: rendahnya kemampuan panitia pelaksana pemilu di tingkat bawah, tidak adanya komunikasi yang jelas antar panitia pelaksana pemilu, dan yang paling parah adalah pelanggaran yang disengaja. Walaupun, alasan terakhir tersebut tidak terbukti secara kuat terjadi dalam pemilihan Gubernur dan Wakil Gubernur Sulawesi Tenggara tahun 2018. Namun demikian, hal tersebut sering terjadi di daerah lain di Indonesia, terutama yang memiliki ikatan primordial dan komunalisme yang masih kuat.

\section{Tingginya Biaya Politik dan Maraknya Politik Uang}

Mengacu regulasi dan ketentuan UU No. 1/2015, pembiayaan pilkada langsung dibebankan dalam Anggaran Pendapatan dan Belanja Daerah. Daerah yang mempunyai kemampuan finansial yang kuat mungkin akan dengan mudah menyelenggarakan pilkada langsung. Sedangkan daerah yang memiliki kemampuan finansial yang rendah akan kewalahan membagikan anggaranya untuk penyelenggaraan pilkada dan kebutuhan pemerintahan ke depan. Apalagi jika daerah tersebut harus melaksanakan pilkada dua putaran. Oleh karena itu, kemampuan keuangan daerah bisa menjadi pertimbangan penting untuk memutuskan sebuah daerah dikatakan siap atau belum dalam menjalankan pilkada langsung. Pada kondisi inilah berkeadilan politik perlu dibahas secra serius.

Pemerintah Provinsi Sulawesi Tenggara telah menetapkan rencana alokasi Anggaran untuk pelaksanaan pilkada tahun 2018 sebesar Rp. 370.767.541,-. Anggaran tersebut diambilkan dari APBD tahun 2017 dan tahun 2018. Total anggaran tersebut juga sudah termasuk dana cadangan untuk pelaksanaan pilkada putaran kedua, yaitu sekitar 10 miliar. Namun demikian, pelaksanaan pilkada di Provinsi Sulawesi Tenggara ternyata cukup berjalan satu kali putaran. Oleh karena itu, pemerintah mendapatkan pengembalian dana dari anggaran pilkada.

Tabel 3 Anggaran Pelaksanaan Pilkada Provinsi Sulawesi Tenggara Tahun 2018

\begin{tabular}{|c|l|c|}
\hline No & Lembaga & Anggaran \\
\hline 1 & KPU Provinsi Sulawesi Tenggara & $248 \mathrm{M}$ \\
\hline 2 & Bawaslu Provinsi Sulawesi Tenggara & $76,4 \mathrm{M}$ \\
\hline 3 & Keamanan Provinsi Sulawesi Tenggara & $7,4 \mathrm{M}$ (tahap I) dan 25 M (tahap II) \\
\hline \multicolumn{2}{c|}{ Total } & $\mathbf{3 5 6 , 8} \mathbf{~ M}$ \\
\hline
\end{tabular}

Sumber: Laporan Pemantauan Perkembangan Politik Pilkada Langsung, 2018. 
Jumlah pengeluaran KPU di atas berbeda jauh dengan pengeluaran pilkada tahun 2013 yang hanya menelan anggaran sekiatar Rp 70 miliar. Jumlah anggaran tersebut bahkan masih terlalu banyak jika dibandingkan dengan biaya yang dikelaurkan pada tahun 2008 yang hanya menelan Rp 35 miliar. Hal tersebut terjadi karena pada tahun 2008 Provinsi Sulawesi Tenggara hanya terdiri atas 10 kabupaten/kota, sementara tahun 2013 terdiri 12 kabupaten/kota. Sementara wajib pilih pada pilkada 2008 hanya 1,3 juta dan pada tahun 2013 hanya mencapai 1,6 juta. Kondisi yang sama juga terjadi dengan usulan anggaran dari Bawaslu tahun 2013 yang hanya disetujui Rp. 12 miliar, dan keamanan yang hanya Rp 7 miliar.

Pilkada langsung berbiaya tinggi juga dirasakan oleh pasangan calon kepala daerah. Para calon kepala daerah setidaknya harus menyiapkan dana untuk mahar partai politik di tingkat pusat, anggota dewan di tingkat daerah, biaya kampanye, dan biaya lain-lain termasuk untuk "uang bensin" bagi pemilih, serta para saksi yang berjuang mengawal pada hari pemilihan. Untuk mahar politik bagi calon bupati setidaknya harus mengeluarkan anggaran sebesar 5-10 miliar per partai pendukung, 1-5 miliar per partai politik untuk wakil bupati, dan lebih dari 15 miliar per partai politik untuk calon gubernur dan wakil gubernur. Biaya tersebut belum termasuk untuk "administrasi”" pengurus partai di tingkat lokal yang dihitung per kursi DPRD maupun untuk biaya "silaturahmi" kepada masyarakat, biaya menerima tamu, kampanye cetak, kampanye daring, serta "uang bensin" pada saat hari pemilihan. Besaran anggaran tersebut masih bisa bertambah tergantung potensi keuangan dan investasi daerah.

Diskusi tentang maraknya politik uang hampir terjadi disetiap pelaksanaan Pilkada langsung. Politik uang bahkan menjadi sesuatu hal yang ditunggu oleh masyarakat dalam setiap pesta rakyat tersebut. Tanpa "uang bensin" tersebut, masyarakat menjadi malas untuk menggunakan hak politiknya di TPS. Adanya politik uang menjadi kesempatan masyarakat untuk merasakan secara langsung pesta demokrasi dan sekaligus memanfaatkan peluang kedermawanan calon pemimpin. Dalam banyak kasus, pejabat yang sudah terpilih mendadak amnesia dengan rakyat. Oleh karena itu, momentum pilkada dimanfaatkan oleh masyarakat untuk mendapatkan uang sebanyak mungkin dari pasangan calon.

\section{Politisasi Birokrasi Pilkada Provinsi Sulawesi Tenggara Tahun 2018}

Sebuah pendapat diutarakan James Manor dan Richard Crook berdasarkan penelitian mereka di Amerika Selatan dan Afrika Barat, terdapat kaitan antara pemilihan langsung 
kepala daerah dengan bad governance. Lebih lanjut, Prasojo menyatakan bahwa ada dampak negatif dari pilkada langsung terhadap pelayanan publik dan penyelenggara pemerintahan, yaitu tingginya kemungkinan kepala daerah untuk mengembalikan ongkos politik pilkada langsung melalui APBD. Upaya untuk menarik simpati, biaya iklan, biaya mendaftar pada partai politik pengusung, dan pembiayaan politik lain menyebabkan tingginya ongkos pilkada langsung bagi para kandidat.

Menganalisis proses pilkada tidak hanya fokus pada tahapan-tahapan pilkada saja. Evaluasi format pilkada sebagaimana telah didefinisikan sejak awal merupakan proses politik yang melibatkan bekerjanya institusi-institusi politik terutama dalam hubungan segitiga antara sistem kepartaian, sistem pemilu khususnya pemilu legislatif, dan sistem pemerintahan. Kepala daerah yang terpilih dalam sistem multipartai di Indonesia akan sulit memperoleh suara yang signifikan. Kualitas kinerja kepala daerah terpilih juga dipengaruhi oleh interaksi timbal balik antara eksekutif dan legislatif.

Oleh karena itu, incumbent cenderung menggunakan kekuasaan untuk memobilisasi dukungan dari birokrasi di daerahnya. Meski secara legal mereka harus netral dalam pilkada, praktiknya di lapangan yang terjadi tidak demikian. Seorang calon kepala daerah yang kebetulan sedang menjabat, sangat memperhitungkan loyalitas bawahan di dalam memenangkan ambisi politiknya. Sebagai akibatnya, mutasi dan rotasi yang terjadi kemudian, tidaklah selalu didasarkan pada merit system, melainkan pada loyalitas dukungan dalam pilkada yang berlangsung sebelumnya.

Data Bawaslu Sulawesi Tenggara (2018) menemukan adanya keterlibatan ASN dalam proses proses pelaksanaan pemilihan gubernur dan wakil gubernur. Baik di tingkat kabupaten/kota maupun provinsi. Adapun jumlah ASN yang terindikasi berpihak pada pasangan calon gubernur dan wakil gubernur Sulawesi Tenggara sebanyak 62 orang dan tersebar di seluruh pasangan calon. Tingkat keterlibatannya pun berbeda-beda. Ada yang secara terang-terangan melibatkan diri dalam kegiatan politik praktis, menggunakan fasilitas negara untuk berkampanye, atau turut serta dalam berkampanye.

Fenomena keterlibatan ASN dalam pilkada memang bukan menjadi rahasia umum. Padahal, dampak yang diakibatkan dengan keterlibatan ASN dalam pilkada sangat buruk. Dalam pilkada di Kabupaten Sorong Selatan, Papua Barat, keterlibatan ASN bahkan mengakibatkan berhentinya roda pemerintahan. ASN yang dianggap tidak mendukung pasangan calon terpilih langsung dimutasi dan bahkan dinonaktifkan tanpa melalui prosedur 
yang jelas. Sementara ASN yang menjadi pendukungnya diangkat menjadi pejabat pemerintahan walaupun tidak memenuhi syarat-syarat administratif.

\section{Analisis Pelaksanaan Pemilihan Gubernur dan Wakil Gubernur Provinsi Sulawesi Tenggara Tahun 2018}

Melihat perjalanan proses pemilihan langsung Gubernur dan Wakil Gubernur Provinsi Sulawesi Tenggara, terdapat beberapa hal menarik untuk dianalisis baik positif dan negatif Jika dilihat dari sudut pandang positif, terdapat beberapa hal yang bisa kita amati. Pertama, kualitas demokrasi di tingkat lokal khususnya di Sulawesi Tenggara sudah semakin meningkat. Kondisi ini setidaknya tercermin dari peningkatan partisipasi memilih masyarakat yang meningkat hingga 4\% dari tahun 2012 hingga 2018.

Kedua, walaupun Sulawesi Tenggara masuk dalam wilayah yang rentan konflik, namun pelaksanaan pemilihan Gubernur dan Wakil Gubernur bisa berjalan dengan normal. Artinya, semua elemen, khususnya aparat keamanan dan penyelenggara pemilu di Indonesia sudah mulai menutup celah munculnya konflik yang disebabkan oleh pilkada langsung.

Ketiga, semakin masifnya pengawasan pilkada langsung yang dilakukan oleh Bawaslu dan juga berbagai elemen masyarakat. Kondisi tersebut tidak terlepas dari komunikasi antar stakeholder dan juga perkembangan informasi yangmemungkinkan pelaksanaan pilkada langsung bisa dilakukan secara transparan.

Keempat, proses pelaksanaan pilkada langsung sejak tahun 2005 sudah menghasilkan pemimpin-pemimpin daerah yang berkualitas Terbukti, semua pasangan calon Gubernur dan Wakil Gubernur Sulawesi Tenggara tahun 2018 merupakan mantan kepala daerah yang sukses di tingkat kabupaten/kota dan sedang berusaha untuk naik kelas menjadi gubernur dan wakil gubernur.

Namun demikian, tidak dapat dipungkiri bahwa pelaksaan pilkada langsung masih dihadapkan pada berbagai permasalahan. Beberapa permasalahan yang muncul dalam pelaksanaan pilkada Sulawesi Tenggara 2018, antara lain. Pertama, masih kuatnya politik identitas dan isu SARA dalam pelaksanaan pilkada langsung di Sulawesi Tenggara. Kompetisi dalam Pilkada Provinsi Sulawesi Tenggara, termasuk kabupaten-kabupatennya, masih mewarisi tradisi perebutan kepemimpinan patrimonial.

Kedua, dukungan partai politik dan anggota DPRD dalam pelaksanaan pilkada langsung tidak menjadi jaminan keterpilihan. Dalam konteks pemilihan gubernur dan wakil gubernur di Sulawesi Tenggara faktor lain yang menentukan antara lain kedekatan dengan 
kelompok tradisional, figur pasangan calon sebagai representasi masyarakat daratan dan kepulauan, serta kekuatan finansial.

Ketiga, munculnya indikasi keterlibatan birokrasi dalam pilkada langsung. Tidak dapat dipungkiri, pelaksanaan pilkada langsung di Sulawesi Tenggara penuh dengan intrik keterlibatan ASN. Kondisi tersebut tidak terlepas dari pasangan calon yang masing-masing merupakan mantan kepala daerah yang tentunya mempunyai „bekal ${ }^{\text {ee }}$ birokrat di wilayahnya.

Keempat, partisipasi pemilih di Provinsi Sulawesi Tenggara tergolong belum maksimal. Kondisi tersebut terjadi salah satunya karena adanya rasa jenuh masyarakat terhadap pilkada langsung yang tidak kunjung memberikan kesejahteraan kepada masyarakat.

Pemilih yang rasional dan otonom di Indonesia dalam konteks pilkada masih sangat sedikit. Banyak kasus menunjukkan bahwa pemilih masih bisa dimobilisasi dengan politik uang maupun isu SARA. Partisipasi elite yang diharapkan bisa mendorong partisipasi politik masyarakat yang otonom ternyata tidak terjadi. Namun yang terjadi justru sebaliknya, elite lebih banyak melakukan tindakan yang kontraproduktif terhadap peningkatan partisipasi otonom masyarakat. Dalam kondisi ini elite politik harus mendorong terjadinya peningkatan kualitas partisipasi masyarakat. Akademisi dan pegiat LSM harus lebih sering melakukan diseminasi ide-ide dan wacana. Partai politik juga diharapakan semakin giat melakukan fungsinya dengan benar terutama dalam aspek pendidikan politik dan rekrutmen politik.

Namun demikian, terlepas dari berbagai dampak positif dan negatif, pelaksanaan pemilihan kepala daerah secara langsung menjadi proses penting dalam perkembangan demokratisasi di tingkat lokal. Pemerintah daerah, dengan adanya pemilihan kepala daerah langsung mempunyai harapan adanya transparansi, akuntabilitas, dan efisiensi dalam pembuatan kebijakan pembangunan ke depan. Selain itu, pelaksanaan pemilihan kepala daerah langsung, khususnya pemilihan gubernur dan wakil gubernur Provinsi Sulawesi Tenggara tahun 2018 juga memberikan banyak pengetahuan bagi perkembangan demokratisasi di tingkat lokal. Khususnya dalam menyikapi pelaksanaan pemilihan gubernur dan wakil gubernur ke depan berdasarkan dinamika yang terjadi saat ini.

\section{KESIMPULAN}

Penelitian ini menyimpulkan bahwa pemilihan Gubernur dan Wakil Gubernur Provinsi Sulawesi Tenggara tahun 2018 tidak terlepas dari berbagai dinamika politik. Secara praktis administratif, pilkada Sulawesi Tenggara tahun 2018 masih banyak ditemukan permasalahan, diantaranya tentang banyaknya daftar pemilih ganda, tidak beresnya logistik 
pilkada, serta masih rendahnya kapasitas penyelenggara Pilkada di tingkat bawah, khususnya kecamatan, desa, dan juga TPS. Sementara itu, jika dilihat dari permasalahan substantif yaitu masih kuatnya politik identitas dan permainan isu SARA, dukungan partai politik dan DPRD tidak menjadi jaminan keterpilihan, kuatnya praktik politik uang, munculnya indikasi keterlibatan birokrasi, maraknya proses pemungutan suara ulang, serta rendahnya partisipasi memilih masyarakat. Dinamika lain yang juga turut memperkeruh suasana yaitu tertangkapnya salah satu calon gubernur oleh Komisi Pemberantasan Korupsi yang berakibat berubahnya peta politik menjelang hari pemilihan.

\section{DAFTAR PUSTAKA}

Akbar, I. (2016). Pilkada serentak dan geliat dinamika politik dan pemerintahan lokal Indonesia. CosmoGov: Jurnal Ilmu Pemerintahan, 2(1), 95-110.

Amirudin \& Zaini, B. (2006). Pilkada Langsung Problem dan Prospek: Sketsa Singkat Perjalanan Pilkada 2005. Yogyakarta: Pustaka Pelajar.

Badan Pusat Statistik Sulawesi Tenggara. 2018. Provinsi Sulawesi Tenggara Dalam Angka 2018. Sulawesi Tenggara: BPS.

Badan Pusat Statistik Sulawesi Tenggara. 2019. Provinsi Sulawesi Tenggara Dalam Angka 2019. Sulawesi Tenggara: BPS.

Bawaslu RI. 2018. Indeks Kerawanan Pemilu Pemilihan Kepala Daera 2018. Jakarta: Bawaslu RI.

Bisariyadi, B., Triningsih, A., \& Rahmawaty, M. (2016). Komparasi Mekanisme Penyelesaian Sengketa Pemilu di Beberapa Negara Penganut Paham Demokrasi Konstitusional. Jurnal Konstitusi, 9(3), 531-562.

Chalid, P. (2005). Pilkada Langsung: Demokratisasi Daerah dan Mitos Good Governance. Jakarta: Partnership

Creswell, J. W. (2013). Research Design: Pendekatan Kualitatif, Kuantitatif dan Mixed. Yogyakarta: Pustaka Pelajar, Edisi Ketiga

Dahl, R. A. (1982). Dilemmas of Pluralist Democracy: Autonomy vs Control. Yale University Press.

Dahl, R. (1989). Democracy and Its Cristics. Yale: Yale University Press

Diamond, L. (1996). Developing Democracy toward Consolidation. London: The John Hopkins University Press.

Dirdjosanjata, P., \& Kana, N. L. (2006). Demokrasi dan Potret Lokal Pemilu 2004. Yogyakarta: Pustaka Pelajar.

Effendy, K. (2010). Memadukan Metode Kuantitaf dan Kualitatif. Bandung: Indra Prahasta.

Gaffar, A. (1999). Politik Indonesia: Transisi Menuju Demokrasi. Yogyakarta: Pustaka Pelajar 
Hanafi, R. I. (2014). Direct Eletion for Local Leaders in Indonesia: Some Critical Notes for Political Parties. Jurnal Penelitian Politik LIPI, 11(2), 1-16.

Jurdi, S. (2010). Muhammadiyah dalam Dinamika Politik Indonesia 1966-2006. Yogyakarta: Pustaka Pelajar.

Kristiadi. J. (2006). Darurat Partai Politik. Jakarta: Ghalia Indonesia.

Lay, C. (2000). Antara Anarki dan Demokrasi: Masalah Kekerasan Politik di Indonesia. Jurnal Ilmu Sosial dan Ilmu Politik, 3(3).

Lay, C. (2007). Pilkada Langsung dan Pendalaman Demokrasi. Jurnal Ilmu Sosial dan Ilmu Politik, 11(1).

Margono, S. (2005). Reformasi Administrasi dan Paradoks Demokrasi. Jurnal Ilmu Sosial dan Ilmu Politik, 9(1).

Mariana, D. (2009). Dinamika Demokrasi dan Perpolitikan Lokal di Indonesia. Bandung: Penerbit AIPI Bandung

Marijan, K. (2010). Sistem Politik Indonesia: Konsolidasi Demokrasi Pasca-Orde Baru. Jakarta: Kencana Prenada Media Group

Masee oed, M. (2003). Negara. Kapital. dan Demokrasi. Yogyakarta: Pustaka Pelajar

Nuryanti, S. (2013). Evaluasi Format Pemilukada Menuju Tata Kelola Pemerintahan yang Baik dan Efektiv di Tingkat Kabupaten/ Kota. Jurnal Ilmu Politik, 10(1).

Nuryanti, S. (2015). Intervensi Penyelenggaraan Pemilukada: Regulasi Sumberdaya dan Eksekusi. Jurnal Ilmu Sosial dan Ilmu Politik, 19(2).

Pahlevi, I. (2011). Pemilihan Gubernur secara Demokratis: Studi terhadap Gagasan Dipilih Kembali oleh DPRD di Provinsi Bengkulu. Jurnal DPD RI, 16(2).

Peraturan Pemerintah Pengganti Undang-Undang Nomor 1 Tahun 2014 Tentang Pemilihan Gubernur, Bupati, Dan Walikota.

Putusan Mahkamah Konstitusi Nomor 97/PUU-XI/2013 Tentang Pengujian Undang-Undang Nomor 12 Tahun 2008 Tentang Perubahan Kedua Atas Undang-Undang Nomor 32 Tahun 2004 Tentang Pemerintahan Daerah Dan Undang-Undang Nomor 48 Tahun 2009 Tentang Kekuasaan Kehakiman Terhadap Undang-Undang Dasar Negara Republik Indonesia Tahun 1945.

Undang-Undang Nomor 22 Tahun 2014 Tentang Pemilihan Gubernur, Bupati, dan Walikota.

Undang-Undang Nomor 23 Tahun 2014 Tentang Pemerintahan Daerah.

Undang-Undang Nomor 10 Tahun 2016 Tentang Perubahan Kedua Atas Undang-Undang Nomor 1 Tahun 2015 Tentang Penetapan Peraturan Pemerintah Pengganti UndangUndang Nomor 1 Tahun 2014 Tentang Pemilihan Gubernur, Bupati, dan Walikota Menjadi Undang-Undang.

Usman \& Megawati, C. (2017). Dinamika Politik: Solusi Akhir Eksistensi Konflik dan Pengaruhnya terhadap Masyarakat Pasca Perdamaian di Aceh Besar. Jurnal Humaniora, 1 (2), 79-86. 